\title{
Preface
}

If we want to solve a problem that we have never solved before, we must leave the door to the unknown ajar. (Richard Feynman ${ }^{1}$ )

Sometimes the Lancashire witches seem very close. The well tower at Lancaster Castle where they were imprisoned, centuries old even then, looms over the city. Inside are rusty iron fittings. Water still drips into hidden wells, and as the ancient studded oak door closes the darkness is that of another age. The cobbled Roman road along which the witches travelled on their final journey to the gallows passes a fine Jacobean residence, used as lodgings for later generations of Assize judges. In front is a memorial to Thomas Covell, the witches' gaoler. Across the city centre the road begins its climb to the moor at the Golden Lion, the site of a pub since 1612 - the year of the witches. The moor itself remains green, occupied now by a playing field, a fine Edwardian park, and St Martin's College. There, generations of history students have learned about the trial of the Lancashire witches, within sight of the castle and close to the spot, now unknown, where those same witches were hanged nearly four centuries before.

In another sense, the Lancashire witches are far away. We (or most of us) no longer believe, as both they and their persecutors believed, that witchcraft is possible. The mental world of the seventeenth century is almost as alien to us as that of the Incas. It was the imaginative study of such alien phenomena as witchcraft that helped fuel the social and cultural history renaissance of the last third of the twentieth century. Many of those scholars have had connections with Lancaster's two higher education institutions, Lancaster University and St Martin's College, although specialist knowledge of the Lancashire witch trials is by no means confined to academics. All this work is underpinned by an unquenchable public interest in this most famous and bestdocumented of all English witch trials. 
Thus it was that a two-day event entitled 'The Lancashire Witches: History, Heritage and Representation 1612-1999' came to be held on 23-24 April 1999. Organised jointly by the Centre for North West Regional Studies, Lancaster University, and St Martin's College, it took place at the College, on what used to be part of the moor, a few hundred yards from an ancient row of cottages whose name preserves the memory of a place of execution: Golgotha. On the first day nearly a hundred participants listened to seven invited speakers - Stephen Pumfrey, Marion Gibson, John Swain, Jonathan Lumby, Kirsteen Macpherson Bardell, Richard Wilson and Sarah Lee - give papers on various aspects of the Lancashire witch trials. After dinner, they reassembled at the King's Arms Hotel, opposite Lancaster Castle, for talks by Ronald Hutton and Joanne Pearson on twentieth-century Wicca and paganism. The next day, a Saturday, two coaches set off to visit the principal sites of the Lancashire witches trail, meeting in Whalley Abbey for a lunchtime paper by Michael Mullett, memorably concluded out of doors in the abbey ruins. Throughout the event there was the exciting sense of a number of different kinds of expertise coming together on the same historical problem to generate new insights. Eight of the ten papers from 1999 are included in this collection. Two further essays have since been added: those by Alison Findlay and Jeffrey Richards. James Sharpe, unable to attend, kindly agreed to read all the papers and to write the introduction.

The result is a book in which experts in a variety of fields bring to bear their expertise on different aspects of the Lancashire witch trials of 1612 and 1633-34: history of science, history of religion, cultural history, social and economic history, English literature, Renaissance studies, religion and theology, and, of course, the specialist history of witchcraft. Seven of them are or have been Lancaster-based, and all have worked extensively on Lancashire sources. Readers will have to assess how successful this book has been in making sense of its subject, and in communicating their findings to those nonspecialists who form the vast majority of those interested in the Lancashire witch trials.

This volume, like the 1999 event which gave rise to it, is aimed at academics and general readers alike. The subject of witchcraft appeals to as wide a range of interests as any historical topic, and it is right and necessary that at least some of the literature should address as many of them as possible. I trust that academic readers will understand that the editorial material is intended mainly for non-specialists, and that non-academic readers will understand that the most rewarding papers may be those whose full meaning is not apparent on a first reading. But the ideal is clarity all round, not least because there are so many different kinds of academic specialism; most of the time, we are all non-specialists. In writing up their papers for publication, the authors have been asked to bear in mind the needs of non-specialist readers from other disciplines and from none, and to write clearly, explaining technical terms and 
allusions. Each was given access to the papers of all the others, and encouraged to make connections. The aim has been to produce a book which can be read with pleasure and profit by people with every kind of interest, and which hangs together as more than the sum of its parts.

This collection is, however, not intended to be one of those tombstone volumes that settle all possible debates. Doubt, not certainty, is the foundation of learning. This volume settles some issues and suggests solutions to many others, but in the end it gives us not less to discuss but more. It does not close off lines of enquiry but opens them up. Its success will be measured by its effect in generating further debates, revelations and new perspectives. The door to the unknown remains open. The Lancashire witches are not dead yet.

\section{Robert Poole}

Lancaster

\section{Notes}

1 Richard P. Feynman, The Pleasure of Finding Things Out (1999; London: Allen Lane, 2000), p. 149. 